\title{
CFTR Gene Transfer and Tracking the CFTR Protein in the Airway Epithelium
}

\author{
Gaëlle Gonzalez, Pierre Boulanger and Saw-See Hong \\ University of Lyon 1 \\ France
}

\section{Introduction}

Cystic fibrosis (CF) is an autosomal recessive genetic disease caused by mutations in a single gene, the cystic fibrosis transmembrane conductance regulator (CFTR) gene. This disease primarily involves epithelial cells of the respiratory system, intestine, pancreas, gall bladder, and sweat glands. Although several organs are affected, the main cause of CF mortality and morbidity is due to pulmonary complications associated with impaired clearance and obstruction by viscous mucus secretions, which makes the lung epithelial cells the principle target for CF treatment. A monogenic disease such as CF was a priori an ideal candidate for gene therapy, as treatment of the disease was thought to be feasible with the introduction of the normal alleles of the CFTR gene into the airway epithelial cells to code for the functional protein.

\section{CFTR gene transfer to the airway epithelium}

The lung can be divided anatomically and physiologically into two regions, (i) the airways, consisting of the trachea, bronchi and bronchioles which brings air to the peripheral lung and (ii) the alveoli where the exchange of gas takes place. The airway epithelium is normally covered by a thin layer of mucus and acts as a natural barrier against foreign particles, including pathogens. In CF individuals, the airways are filled with sputum consisting of inflammatory cells, cell debris, highly viscous mucus and DNA, causing obstruction of the airways, constituting the major barrier for gene transfer as it prevents the cellular uptake of the vectors by the airway epithelial cells (Griesenbach, Alton et al., 2009; Hida et al., 2011).

The main target tissue for CF gene therapy is believed to be the airway epithelium, which exhibits all ion transport functions of CFTR and is easily accessible. However, the nature of the cells which are the best target for CF gene therapy is still debatable. The transfer of genes to the airway results in gene expression primarily in lung epithelial cells, and the transgene is localised to the lung without much systemic distribution. The highest level of CFTR gene expression is found in the bronchial submucosal gland cells (Merten et al., 1996; Kammouni et al., 1999; Chow et al., 2000) and it was suggested that these glandular cells may be better reached by vasculature and systemic application of the vector rather than by the airways (Boucher, 1999 ; Kolb et al., 2006). 
There are several ways of introducing therapeutic genes into human cells but the most efficient method of gene transfer into human cells is by the use of viral vectors. Viruses have evolved and developed natural strategies to enter, transfer their genetic material and reproduce in specific tissues of their hosts, making them highly adapted as vectors to transfer genes into their natural target cells. Since 1989, twenty-nine clinical trials for CF have been carried out using adenovirus or adeno-associated virus vectors and non-viral vectors. In these gene therapy protocols, the major site of vector administration was the respiratory airways such as the nasal and lung epithelium. Unfortunately, the somewhat disappointing results of these clinical trials showed that CF gene therapy was more difficult than originally anticipated. The viral and non-viral vectors used in these trials revealed their limitations and inefficacy in gene transfer to the human airway epithelium.

\subsection{Adenovirus (Ad) vector}

The adenovirus as a gene transfer vector has several advantages over other vectors: (i) its capacity to incorporate large transgenes; (ii) its ease for genetic manipulation (Hong et al., 2003; Magnusson et al., 2007; Magnusson et al., 2001 ); and (iii) its facility to be produced to high titres. The efficiency of Ad vectors in gene transfer has been demonstrated in numerous systems (Henning et al., 2002; Gaden et al., 2004; Toh et al., 2005) and the functional analysis of transgenes expressed by Ad can be tested in vitro in cell lines, ex vivo in tissues and in vivo in animal models. In vitro studies demonstrated that recombinant Ad vectors can express CFTR in cultured CF airway epithelial cells and correct the $\mathrm{Cl}^{-}$transport defect (Zabner et al., 1993). Following this, a number of in vivo studies in animals and in tracheal explants showed that Ad vectors can express CFTR as well as reporter genes in the airway epithelia (Rosenfeld et al., 1992; Harvey et al., 1999; Scaria et al., 1998 ).

Ten CF clinical trials involving Ad vectors were conducted during the period 1993-2001 (available in Clinical Trials website: http://www.wiley.com//legacy/wileychi/ genmed/clinical/). The first Ad vector used in $\mathrm{CF}$ gene therapy trials involving $\mathrm{CF}$ patients was a serotype $2(\mathrm{Ad} 2)$ vector, genetically modified in the E1 region to carry the CFTR cDNA, under the E1a promoter and had the same polyadenylation addition site as the E1b and pIX transcripts (Zabner et al., 1993). The results obtained from the early clinical trials with Ad vector administration in the nasal and pulmonary tissues showed that the Ad vectors were well-tolerated at low to intermediate doses in humans, and partially corrected the chloride transport (Zabner et al., 1993, Crystal, 1995; Welsh et al., 1995; ).

One major difficulty which was revealed from the clinical trials was the inefficient CFTR gene transfer to the airway epithelium of CF patients (Perricone et al., 2001). It is known today that several factors were responsible for the low efficiency of CFTR gene transfer (Crystal, 1995): (i) the nonspecific inflammatory reactions (Otake et al., 1998) and immune response to the Ad-CFTR vector (Gahery-Segard et al., 1998 ; Piedra et al., 1998); (ii) the airway epithelial cells lack high affinity receptors for Ad (Zabner et al., 1997), as these receptors have a basolateral localization, which makes them inaccessible to Ad-CFTR vectors (Walters et al., 1999); (iii) mechanical factors, like bronchial mucus (Arcasoy et al., 1997 ; Perricone et al., 2000; Hida et al., 2011), or local bacterial infections, can negatively influence the effective binding of Ad vectors to the surface of epithelial cells, and the subsequent delivery of the therapeutic gene; (iv) a combination of the above different 
mechanisms, or/and intrinsic properties of differentiated airway epithelial cells (Gaden et al., 2002). Another hurdle encountered with Ad vectors was that gene transfer to the airway epithelia was transient and the use of recombinant adenovirus vectors would require repeated administration. The requirement for repeated vector administration is a major concern as this will generate neutralizing antibodies against the vector in gene therapy recipients which would subsequently reduce gene transfer efficacy.

\subsection{Adeno-associated virus (AAV) vector}

AAV gene transfer vectors have attracted much interest due to their good safety profile (no known pathology has been found to be associated with AAV in humans), broad tissue tropism and more importantly prolonged gene expression due to the integration of their DNA into the cellular genome. These vectors are thought to exhibit less inflammatory and immune reactions than the adenovirus. However, there are still technical problems concerning the small cloning capacity which could barely accommodate the CFTR gene (4.7 $\mathrm{kb})$, and the difficulty in achieving high titers during AAV vector production.

Six CF gene therapy clinical trials using AAV vectors were carried out from $1999-2007$ (Clinical Trials website: http://www.wiley.com//legacy/wileychi/genmed/clinical/). The first AAV-CFTR vector used showed physiological correction of chloride transport in nasal epithelial cells in gene therapy recipients, even in those with low CFTR mRNA expression (Wagner JA et al, 1999). The more recent clinical trials used the AAV vector, TgAAV-CFTR, developed by Targeted Genetics Corp, which carried the weak AAV long terminal repeat (LTR) promoter to drive CFTR gene expression (Griesenbach et al., 2009). The clinical data showed that repeated doses of aerosolised AAV-CFTR vector treatment did not result in significant therapeutic improvement (Moss et al., 2007). The reasons for these disappointing results could likely be that (i) AAV was inefficient in transducing airway epithelial cells via the apical membrane, (ii) the LTR promoter used to drive CFTR expression was too weak, or (iii) repeated administration of AAV to the lung resulted in the development of an anti-viral immune response (Griesenbach et al., 2009). In brief, the vector was well tolerated but there are still concerns about the toxicity and immunological responses related to the repeated administration of this vector. In addition, it was reported recently that insertional mutagenesis was observed in neonatal mice models treated with recombinant AAV vectors: the mice developed hepatocellular carcinoma which was associated with AAV vector integration (Dosante et al., 2007).

\subsection{Non-viral vectors}

Nine CF gene therapy clinical trials have been carried out using non-viral or synthetic vectors from 1995-2004 (Clinical Trials website: http://www.wiley.com//legacy /wileychi/genmed/clinical/). There are three main non-viral vector systems: cationic liposomes, DNA-polymer conjugates and naked DNA. Non-viral vectors have their limitations such as (i) low efficiency in gene transfer as compared to viral vectors, and (ii) loss of efficacy with repeated administrations. However, the major advantage of these vectors is that they are less immunogenic compared to Ad and AAV vectors. Their inefficacy is mainly due to intracellular barriers such as endosomal sequestration and cytoplasmic degradation, where $\mathrm{Ca}^{2+}$-sensitive cytosolic nucleases restrict the half-life of DNA to 50-90 
mins (Pollard et al., 2001). The nuclear membrane of non-dividing, airway epithelial cells constitutes another intracellular barrier as the nuclear entry of exogenous DNA occurs only in cells that are actively dividing (Ferrari et al., 2002).

To date, only cationic liposome-based systems have been tested in CF clinical trials. The first cationic liposome vector used was DC-Chol $\left(3 \beta\left\{N-\left[N^{\prime}, N^{\prime}\right.\right.\right.$-dimethylaminoethane $]$ carbamoyl $\}$ cholesterol) mixed with DOPE (dioleoylphosphatidyl ethanolamine), complexed to CFTR plasmid DNA, and administered to patients via the nose. Cationic liposomes facilitate gene transfer by their interaction with DNA via their positively charged side chains and enhancing fusion with the host cell membrane via the hydrophobic lipid portion. The results obtained were encouraging as partial restoration of CFTR function was observed. However, the transfection efficiency and the duration of expression would need to be increased for therapeutic benefit (Caplen et al., 1995). Improvements to non-viral vector gene transfer efficiency to the lung have been proposed by using DNA condensed to molecular conjugates carrying a 17 amino acid peptide ligand which targets the serpinenzyme complex receptor expressed on the apical surface of airway epithelial cells (Ziady et al., 2002).

Recently, three non-viral gene transfer agents: (i) cationic liposome (GL67A), (ii) compacted DNA nanoparticle with polyethyleneglycol-substituted lysine 30-mer (NP) and, (iii) 25kDa-branched polyethyeneimine (PEI) were evaluated in vivo in a sheep lung model. The efficacy profile of these agents to deliver a plasmid carrying the CFTR cDNA to the ovine airway epithelium by aerosol administration was compared. The results showed that GL67A was overall the best gene transfer agent for aerosol delivery to the sheep lung, and was selected for clinical trials in CF patients (McLachlan et al., 2011). In an ongoing clinical trial by the UK CF Gene Therapy Consortium and funded by the CF Trust, CF patients were given a single dose of a plasmid carrying the CFTR cDNA, complexed to the cationic lipid GL67A. This initial single-dose clinical trial will assess the safety and duration of CFTR expression in patients. Another clinical trial is planned for to determine whether repeated non-viral CFTR gene transfer (12 doses over 12 months) will improve CF lung disease (Sinn et al., 2011).

\section{Tracking the CFTR in cells using GFP-CFTR fusion protein}

The green fluorescent protein (GFP) is a $27-\mathrm{kDa}$ protein from the jellyfish Aequorea victoria, discovered by Shimomura and co-workers in the 1960's and was shown to emit bright green fluorescence under UV light (Shimomura et al., 1962). It took another 30 years before this protein was cloned and its functionality demonstrated in different organisms (Prasher et al., 1994 ; Chalfie et al. 1994; Inouye and Tsuji 1994 ; Tsien, 1998). The GFP is widely used today as a biological marker in cell biology and gene transfer technology. The GFP can be detected in living cells without selection or staining, and be genetically fused to other proteins to produce fluorescent chimeras and generally does not alter the function or cellular localization of the fusion protein (Gerdes and Kaether, 1996 ; Lippincott-Schwartz and Smith, 1997). It is used as a reporter protein for studying complex biological processes such as organelle dynamics and protein trafficking. In gene transfer experiments, the GFP serves an in vivo marker, allowing for the determination of gene transfer efficiency and for selection of cells positive for the transgene. Other applications of GFP in gene therapy involve the use of GFP-tagged 
therapeutic proteins to determine the site, level and duration of expression, or for the correlation between gene transfer efficiency and therapeutic outcome (Wahlfors et al., 2001).

\subsection{Construction and in vitro applications of GFP-CFTR}

The CFTR protein is a 1,480 residue glycosylated molecule with 12 transmembrane domains and 3 intracytoplasmic domains (Figure 1). The protein is highly glycosylated at two asparagine residues on the extracellular loop 4, in both the immature and matureglycosylated forms (Sheppard and Welsh, 1999). The immature CFTR has a high content of oligosaccharides of the mannoside type, and exists in the endoplasmic reticulum as a precursor before its transit to the trans-Golgi network. During the transit, the CFTR is processed into its mature form with the addition of complex carbohydrate chains containing polylactosaminoglycan sequences (O'Riordan et al., 2000). A functional CFTR requires the protein to be fully glycosylated, and its function as a chloride channel in epithelial cells is dependent on its cellular trafficking and transport to the apical membrane.

The first direct visualization of the CFTR protein within cells was made possible by the genetic fusion of the green fluorescent protein (GFP) to the N-terminus of the CFTR protein. The choice of adding the GFP-tag at the N-terminus (Figure 1) was such that it would have minimal interference with the membrane-targeting signal thought to be encoded in the C-terminus of the protein (Milewski et al., 2001; Moyer et al., 1998). Functional and cell trafficking studies of the CFTR protein and its mutants were made possible with the expression of the GFP-fused protein in different cell lines, using expression plasmids (Moyer et al., 1999; Loffing-Cueni et al., 2001; Haggie, Stanton, and Verkman, 2002). The GFP-CFTR fusion construct displayed functionality in terms of apical membrane localisation in Madin-Darby Canine Kidney (MDCK) cells. Short circuit current measurements showed that the protein mediated cAMP-activated transepithelial chloride transport across monolayers of stably transfected MDCK cells (Moyer et al., 1998). Studies of the dynamics of CFTR protein responses to bacterial infections, the manner by which the CFTR protein responds to, interacts with, and mediates translocation of $P$. aeruginosa and serovar $S$. typhi from the cell surface into the cell were also done using a GFP-CFTR fused protein (Gerçeker et al., 2000).

\section{Extracellular domains}

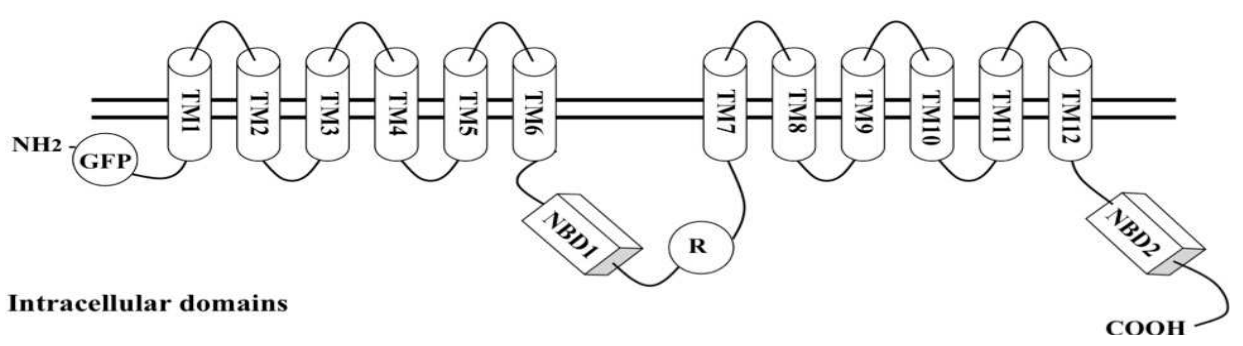

Fig. 1. Schematic representation of the GFP-CFTR fusion protein and the topology of the different domains. The GFP is located on the N-terminus of the CFTR protein. GFP, green fluorescent protein ; TM, transmembrane domain ; NBD1, nucleotide binding domain 1 ; NBD2, nucleotide binding domain 2 ; R, regulatory domain ; $\mathrm{NH} 2$, protein aminoterminus ; $\mathrm{COOH}$, protein carboxyterminus. 


\subsection{Ex vivo applications of GFP-CFTR}

The GFP-CFTR fusion constructs have also been inserted into viral vectors such as Adenovirus (Vais, 2004; Granio et al., 2007; Granio et al., 2010) and Sendai virus (Ban et al., 2007) to facilitate the detection and direct tracking of the protein after gene transfer. When the Ad vectors, Ad5-GFP-CFTR and Ad5-GFP-CFTR $\triangle$ F508, were used to transduce reconstituted airway epithelium from $\triangle \mathrm{F} 508 \mathrm{CF}$ patients, the biologically active GFP-CFTR and the mutant GFP-CFTR $\triangle F 508$ proteins could be directly tracked in the epithelial cells by confocal fluorescence microscopy due to their GFP-tag (Granio et al., 2007 ; see Figure 2, A and B). The GFP-CFTR protein (green) was observed to be located on the apical membrane of the reconstituted airway epithelium, at the same plane as the ZO-1 protein (red) which is the marker for tight junctions at the apical membrane. The nuclei of the cells were stained blue with DAPI (Figure 2, A and B). In epithelial cells infected with the Ad5 expressing the GFP-CFTR $\triangle$ F508, the fluorescence was observed in the central and basal areas of the cytoplasm and none expressed at the apical surface (Figures 2, B and D). This was the first report showing the direct localization of an exogenous GFP-tagged CFTR protein on reconstituted human epithelial cells after Ad-mediated gene transfer (Granio et al., 2007).
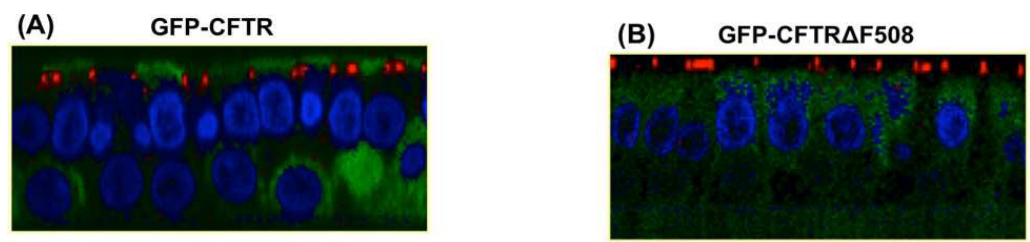

\section{(C)}

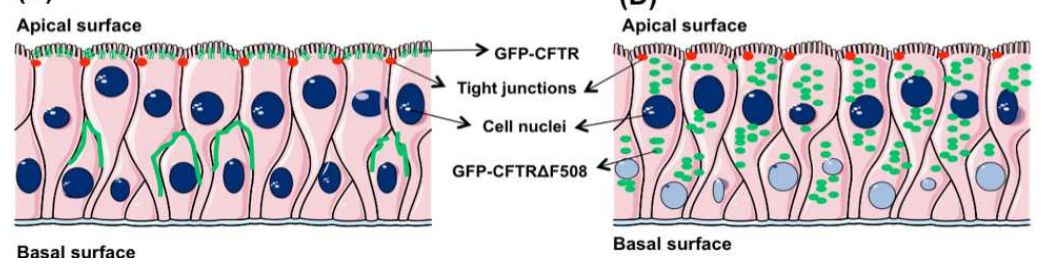

Fig. 2. Cellular localisation of the GFP-CFTR and GFP-CFTR $\triangle F 508$ protein in ex vivo reconstituted human airway epithelium after gene transfer with Ad5-GFP-CFTR (A) and Ad5-GFP-CFTR $\triangle$ F508 (B). (A), (B) : reconstructed images of sagittal sections of transduced epithelia generated from the $\mathrm{z}$-stack images obtained in confocal fluorescence microscopy. (C), (D) : schematic representation of the images shown in (A) and (B), respectively.

The availability of appropriate cell receptors at the apical surface of airway epithelial cells is a crucial factor for the efficient uptake of viral vectors. A majority of viral vectors such as Adenovirus, AAV, Measles virus and pseudotyped retroviruses can only infect airway epithelial cells via the basal membrane (Kremer et al., 2007; Sinn et al., 2002; Teramoto et al., 1998; Zabner et al., 1997). Airway epithelial cells are not easily transduced by Ad5based vectors as the Coxsackie-Adenovirus Receptor (CAR), a high affinity receptor for Ad5 and many other Ad serotypes vectors are mainly localised in the tight junctions and not at the apical surface (Walters et al., 1999), and thus not accessible to Ad vectors. One strategy of overcoming this physical barrier was to design an Ad vector which will 
recognise a receptor expressed on the apical surface of airway epithelium. The Ad serotype 35 (Ad35) or a chimeric Ad5F35 vector (a serotype 5 capsid carrying serotype 35 fibers), which both recognise CD46 as receptor, a molecule found on the apical surface of human airway epithelium (Gaggar, Shayakhmetov, and Lieber, 2003; Sinn et al., 2002; Corjon et al., 2011) would be capable of directly infecting the airway epithelia from the apical membrane .

The demonstration was recently made with a chimeric Ad5F35 vector expressing GFPCFTR. This chimeric vector transduced efficiently well-differentiated human airway epithelium via the apical membrane and showed stable expression of the GFP-CFTR protein. Measurements of transepithelial ion transport showed the correction of the chloride channel function at relatively low vector doses in $\triangle F 508 \mathrm{CF}$ airway epithelial cells (Granio et al., 2010). This is a successful example of a viral vector which was genetically modified to target a receptor on the apical surface of the airway epithelial cells for efficient gene transduction. In a separate study using an in vivo mice model, the Ad5F35 vector was found to preferentially target the lungs of CD46-transgenic mice after systemic administration of the vector (Greig et al., 2009). The chimeric Ad5F35 vector therefore shows promise as an efficient lung targeted gene transfer vector for CF.

\subsection{In vivo applications of GFP-CFTR}

A study was conducted to determine whether a GFP-CFTR fusion protein was functional as a transgene when expressed in vivo, in colonic and airway epithelial cells of CF mice, and had the capacity to correct the CF defect. To assess the in vivo function of the GFPCFTR, bitransgenic mice $c f t r \sim S s 1 D / \sim 551 D$ KI8-GFP-CFTR +/- were obtained by breeding K 18-GFP-CFTR mice to $c f t r c 551 D / c 551 D$ CF mice. The analysis of transcripts, protein and electrolyte transport in the colon and airways indicated that the K18-GFP-CFTR was expressed and partially restored the ion transport in the G551D CF mice model. Thus, it appeared that in vivo, the GFP-CFTR fusion protein was capable of supporting the complex interactions required to regulate epithelial chloride transport (Oceandy et al., 2003).

\section{Development of new vectors for CFTR transfer}

\subsection{Human parainfluenza virus}

The human parainfluenza virus type 3 (PIV3) can infect the human airway epithelium and specifically targets ciliated epithelial cells (Zhang et al., 2005). In vitro studies using PIV3based vectors for CFTR gene transfer to CF epithelial cells resulted in the complete reversal of the CF phenotype, with the transepithelial ion transport, airway surface liquid volume regulation and mucus transport, restored to levels observed in non-CF epithelial cells (Zhang et al., 2009). In vivo administration of a PIV3 vector carrying a transgene coding for the rhesus $\alpha$-fetoprotein (rhAFP) to the nasal epithelium of the rhesus macaque (Macaca mulatta) showed expression and secretion of the rhAFP in the mucosal and serosal compartments. The transgene expression was transient and paralleled vector persistance, suggesting that as PIV3 was cleared, rhAFP expression was lost (Zhang et al., 2010). The specificity of the PIV3 vectors for the airways make them particularly interesting as gene transfer vectors for CF therapy. 


\subsection{Respiratory syncytial virus}

The respiratory syncytial virus (RSV) can infect the lungs of CF patients, despite the physical barriers of the respiratory tract, such as the sticky and mucus-rich environment of the $\mathrm{CF}$ lung. In addition, this virus has a natural tropism for the luminal ciliated cells of the airways (Zhang et al., 2002). It was suggested that since RSV has the capacity for reinfections, repeated administrations of an RSV-based vector would be possible. Recently, it was demonstrated that a RSV vector carrying the CFTR gene can infect both non-CF and CF airway epithelium, and in particular the ciliated cells. In CF cells, the CFTR was expressed at the apical surface and showed correction of chloride channel activity which was equivalent in level observed in normal human airway epithelial cultures. Further studies in animal models are needed to determine the immune response to this vector, as well as its persistence in single and repeated administration (Kwilas et al., 2010).

\subsection{Integrative vectors}

The major goal of gene therapy is to have the delivered transgene safely and stably maintained in replicating cells. One approach to achieve genetic stability is via integration of the transgene into the host cell genome, using integrating vectors such as retrovirus and AAV vectors. The main dangers of integrative vectors are their uncontrolled or random integration which can cause (i) transgene silencing if the insertion occurs in condensed heterochromatin, or (ii) insertional mutagenesis if the integration event occurs near growthpromoting genes leading to oncogenesis. The latter was encountered with lentivirus and AAV vectors, in animal models as well as in human clinical trials (Donsante et al., 2007; Hacein-Bey-Abina S, 2003 ).

Just as for Ad vectors, lentiviral gene transfer to the human airway epithelium is inefficient due to the lack of receptors. The strategy of "pseudotyping" or substitution of the lentivirus envelope with the envelope protein of another virus, such as Ebola virus (Kobinger et al., 2003), baculovirus (Sinn et al., 2008) or Sendai virus (Mitomo et al., 2010) have demonstrated increase in gene transfer efficiency to the airway epithelium. Before the application of lentiviral vectors for pulmonary gene transfer, preclinical studies in large animal models will need to be carried out to carefully assess their efficacy and safety.

\subsection{Episomal vectors}

Extrachromosomal or episomal vectors are gene transfer agents which has the capacity of persisting in the nucleus of transduced cells without integrating into the host genome. Due to their nonintegrative nature, there is theoretically no risk of the physical disruption of the cell genome. In addition, episomal vectors can persist in multiple copies per cell, resulting in high expression of the therapeutic gene (Lufino, Edser, and Wade-Martins, 2009). Many of the episomal systems which has been developed are based on sequences derived from viruses such as the Epstein-Barr and Polyoma viruses, which have certain phases of their viral life cycle maintained episomally. The two major requirements of episomal vectors are the presence of a viral origin of replication and the expression of a virally encoded protein which is necessary for vector replication and its repartition into the daughter cells upon cell division. 


\subsubsection{Polyoma-derived episomal vectors}

The first stable episomal plasmid vector described in the literature contained sequences derived from the BK virus which belongs to the polyomavirus family. This episomal vector which carried most of the BK viral genome could persist at a stable copy number of 20-120 copies/cell, depending on the cell line used, and showed low percentage of integration events (Milanesi et al., 1984). Its replication depended on the presence of the BK-derived origin of replication and a transactivating factor, a viral protein called large $\mathrm{T}$ antigen, which is responsible for binding to the viral origin of replication and mediating the vector replication. Replicating vectors based on Simian Vacuolating virus 40 (SV40) were among the first viral-based episomal systems to be developed. SV40 is a nonenveloped DNA virus with a double-stranded genome belonging to the family of polyomaviruses (Vera and Fortes, 2004). The SV40-derived vectors are composed of a cis-acting elements, essentially the SV40 origin of replication, and the sequence encoding for the SV40 T antigen.

\subsubsection{Epstein-Barr-derived episomal vector}

The major progress toward the development of an efficient episomal gene transfer vector came from plasmids based on the Epstein-Barr virus (EBV), a member of the family of herpesviruses. The EBV is capable of life-long persistence as an extrachromosomal, circular multicopy plasmid carried by B-lymphocytes in a latent state (Lindahl et al., 1976). The origin of replication (oriP, origin of plasmid replication) of EBV requires the trans-acting factor EBV Nuclear Antigen-1 (EBNA-1) for replication (Rawlins et al., 1985; Yates, Warren, and Sugden, 1985). The EBNA-1 binds to metaphase chromosomes and interphase chromatin, and this interaction facilitates the partition of oriP plasmids into daughter cells during mitosis (Ito et al., 2002). Plasmid constructs containing EBV episomal elements have been tested in pre-clinical animal models for treatment of diseases such as hemophilia and diabetes. The delivery of the EBV-based episomes were made by injections to the target tissues. Although the efficacy of transduction was less efficient in vivo compared to viral vectors, long term expression of the therapeutic gene was obtained (Mei et al., 2006 ; Yoo et al., 2006).

\subsubsection{Adeno-EBV hybrid episomal vector}

A hybrid Adenovirus-EBV (Ad-EBV) episomal vector has a major interest as it exploits the advantages of both vectors, combining the efficiency of gene transfer of the Ad vector with the episomal replicative nature of the EBV vector. Helper-dependent adenovirus (HD-Ad) vectors which are deleted of all viral coding regions, also known as gutless Ad, (Kochanek et al., 1996 ; Parks et al., 1996), are also interesting vectors as they are less immunogenic. The use of HD-Ad vectors for the development of episomal Ad-EBV vector brings further advantage to these vectors for their use in gene therapy.

Circular replicating Ad-EBV vectors can be obtained by co-infecting an adenovirus carrying EBNA-1 and oriP elements with a loxP site at both ends, with a second adenovirus encoding Cre recombinase, whose expression will result in the circularisation of the first virus (Dorigo et al., 2004; Gallaher et al., 2009). Another strategy described for obtaining circular Ad episomes which does not rely on the expression of a viral protein such as EBNA-1, was based on the human origin of replication derived from the lamin B2 locus with the site- 
specific FLPe recombinase and Frt recognition sites. This vector system produces circular episomes free of viral coding or bacterial DNA sequences (Kreppel and Kochanek, 2004). A more recent study described the development of an HD-Ad-EBV vector in which Cre recombinase is transiently expressed from a hepatocyte-specific promoter such that the vector generation and transgene expression are tissue specific. The results obtained using this strategy were highly promising as long-term persistence of the circularized vector DNA and stable transgene expression in hepatocytes was observed in immunocompetent mice (Gil et al., 2010).

\section{Conclusions}

Profitable lessons have been drawn from the past two decades of CF gene therapy trials using different transfer vectors. The numerous difficulties and problems encoutered have helped in the improvement and design of future gene transfer vectors. New viral vectors such as RSV and PIV which specifically targets cilliated lung epithelial cells have been developed for pulmonary gene transfer. Significant improvement have been made for high-density Ad episomal vectors to achieve efficiency and specificity of transduction, coupled to long-term vector persistance and stable transgene expression. In parallel, the GFP has served as a very useful in vivo marker for the evaluation of gene transfer vectors. The visualization of CFTR protein in situ by means of the GFP fluorescent tag has contributed towards a better comprehension of CFTR multiple functions such as its cellular trafficking and the dynamics of its interactions with intracellular as well as extracellular partners.

\section{Acknowledgments}

The authors are grateful to the French Cystic Fibrosis Foundation (Vaincre la Mucoviscidose, VLM) and the University of Lyon 1 for their support. GG is financially supported by a doctoral fellowship from VLM. SSH is an INSERM Research Associate. PB is Emeritus Professor of the University of Lyon 1.

\section{References}

Arcasoy, S.M., Latoche, J., Gondor, M., Watkins, S. C., Henderson, A., Hughey, R., Finn, O.J., \& Pilewski, J.M. (1997). MUC1 and other sialoglycoconjugates inhibit adenovirus-mediated gene transfer to epithelial cells. Am. J. Respir. Cell Mol. Biol. $17,422-435$.

Ban, H., Inoue, M., Griesenbach, U., Munkonge, F., Chan, M., Iida, A., Alton, E.W.F. W., \& Hasegawa, M. (2007). Expression and maturation of Sendai virus vector-derived CFTR protein: functional and biochemical evidence using a GFP-CFTR fusion protein. Gene Ther. 14, 1688-1694.

Boucher, R. C. (1999). Status of gene therapy for cystic fibrosis lung disease. J. Clin. Invest. $103,441-445$.

Caplen, N.J., Alton, E.W., Middleton, P.G., Dorin, J.R., Stevenson, B.J., Gao, X., Durham, S.R., Jeffery, P.K., Hodson, M.E., Coutelle, C., Huang, L., Porteous, D.J., Williamson, 
R., \& Geddes, D.M. (1995). Liposome-mediated CFTR gene transfer to the nasal epithelium of patients with cystic fibrosis. Nat. Med. 1, 39-46

Chalfie, M., Tu, Y., Euskirchen, G., Ward, W.W. \& Prasher, D.C. (1994). Green fluorescent protein as a marker for gene expression. Science 263, 802-805.

Chow, Y.H., Plumb, J., Wen, Y., Steer, B.M., Lu, Z., Buchwald, M., \& Hu, J. (2000). Targeting transgene expression to airway epithelia and submucosal glands, prominent sites of human CFTR expression. Mol. Ther. 2, 359-367.

Corjon, S., Gonzalez, G., Henning, P., Grichine, A., Lindholm, L., Boulanger, P., Fender, P. \& Hong, S.S. (2011). Cell entry and trafficking of human adenovirus bound to blood factor $X$ is determined by the fiber serotype and not hexon:heparan sulfate interaction. PLoS One, 6, e18205.

Crystal, R. G. (1995). Transfer of genes to humans: early lessons and obstacles to success. Science 270, 404-410.

Donsante, A., Miller, D.G., Li, Y., Vogler, C., Brunt, E. M., Russell, D.W., \& Sands, M.S. (2007). AAV vector integration sites in mouse hepatocellular carcinoma. Science 317, 477.

Dorigo, O., Gil, J. S., Gallaher, S.D., Tan, B.T., Castro, M.G., Lowenstein, P.R., Calos, M. P., \& Berk, A.J. (2004). Development of a novel helper-dependent adenovirus-EpsteinBarr virus hybrid system for the stable transformation of mammalian cells. J. Virol. 78, 6556-6566.

Ferrari, S., Geddes, D.M., \& Alton, E.W.F.W. (2002). Barriers to and new approaches for gene therapy and gene delivery in cystic fibrosis. Adv. Drug Deliv. Rev. 54, 13731393.

Gaden, F., Franqueville, L., Hong, S.S., Legrand, V., Figarella, C., \& Boulanger, P. (2002). Mechanism of restriction of normal and cystic fibrosis transmembrane conductance regulator-deficient human tracheal gland cells to adenovirus infection and admediated gene transfer. Am. J. Respir. Cell Mol. Biol. 27, 628-640.

Gaden, F., Franqueville, L., Magnusson, M.K., Hong, S.S., Merten, M.D., Lindholm, L., \& Boulanger, P. (2004). Gene transduction and cell entry pathway of fiber-modified adenovirus type 5 vectors carrying novel endocytic peptide ligands selected on human tracheal glandular cells. J. Virol. 78, 7227-7247.

Gaggar, A., Shayakhmetiv, D.M., \& Lieber, A. (2003). CD46 is a cellular receptor for group B adenoviruses. Nat. Med. 9, 1408-1412.

Gahery-Segard, H., Farace, F., Godfrin, D., Gaston, J., Lengagne, R., Tursz, T., Boulanger, P., \& Guillet, J. G. (1998). Immune response to recombinant capsid proteins of adenovirus in humans: antifiber and anti-penton base antibodies have a synergistic effect on neutralizing activity. J. Virol. 72, 2388-2397.

Gallaher, S.D., Gil, J.S., Dorigo, O., \& Berk, A.J. (2009). Robust in vivo transduction of a genetically stable Epstein-Barr virus episome to hepatocytes in mice by a hybrid viral vector. J. Virol. 83, 3249-3257.

Gerçeker, A.A., Zaidi, T., Marks, P., Golan, D.E., \& Pier, G.B. (2000). Impact of heterogeneity within cultured cells on bacterial invasion: analysis of Pseudomonas aeruginosa and Salmonella enterica Serovar Typhi entry into MDCK cells by using green fluorescent 
protein-labelled cystic fibrosis transmembrane conductance regulator receptor. Infect. Immun. 68, 861-870.

Gerdes, H.H., \& Kaether, C. (1996). Green fluorescent protein: applications in cell biology. FEBS Lett. 389, 44-47.

Gil, J.S., Gallaher, S.D., \& Berk, A.J. (2010). Delivery of an EBV episome by a selfcircularizing helper-dependent adenovirus: long-term transgene expression in immunocompetent mice. Gene Ther. 17, 1288-1293.

Granio, O., Ashbourne Excoffon, K.J.D., Henning, P., Melin, P., Norez, C., Gonzalez, G., Karp, P.H., Magnusson, M.K., Habib, N., Lindholm, L., Becq, F., Boulanger, P., Zabner, J., \& Hong, S.S. (2010). Adenovirus 5-fiber 35 chimeric vector mediates efficient apical correction of the cystic fibrosis transmembrane conductance regulator defect in cystic fibrosis primary airway epithelia. Hum. Gene Ther. 21, 251269.

Granio, O., Norez, C., Ashbourne Excoffon, K.J.D., Karp, P.H., Lusky, M., Becq, F., Boulanger, P., Zabner, J., \& Hong, S.S. (2007). Cellular localization and activity of Ad-delivered GFP-CFTR in airway epithelial and tracheal cells. Am. J. Respir. Cell Mol. Biol. 37, 631-639.

Greig, J.A., Buckley, S.M., Waddington, S.N., Parker, A.L., Bhella, D., Pink, R., Rahim, A.A., Morita, T., Nicklin, S.A., McVey, J.H., \& Baker, A.H. (2009). Influence of coagulation factor $X$ on in vitro and in vivo gene delivery by adenovirus (Ad) 5 , Ad35, and chimeric Ad5/Ad35 vectors. Mol. Ther. 17, 1683-1691.

Griesenbach, U., Alton, E.W.F.W., \& Consortium., o. b. o. t. U. C. F. G. T. (2009). Gene transfer to the lung: Lessons learned from more than 2 decades of $\mathrm{CF}$ gene therapy. Adv. Drug Del. Rev. 61, 128-139.

Griesenbach, U., Geddes, D.M., \& Alton, E.W.F.W. (2004). Gene therapy for cystic fibrosis: an example for lung gene therapy. Gene Therapy 11, S43-S50.

Hacein-Bey-Abina, S., Von Kalle C., Schmidt, M., McCormack, M.P., Wulffraat, N., Leboulch, P., Lim, A., Osborne, C.S., Pawliuk, R., Morillon, E., Sorensen, R., Forster, A., Fraser, P., Cohen, J.I., de Saint Basile, G., Alexander, I., Wintergerst, U., Frebourg, T., Aurias, A., Stoppa-Lyonnet, D., Romana, S., Radford-Weiss, I., Gross, F., Valensi, F., Delabesse, E., Macintyre, E., Sigaux, F., Soulier, J., Leiva, L.E., Wissler, M., Prinz, C., Rabbitts, T.H., Le Deist, F., Fischer, A., \& Cavazzana-Calvo, M. (2003). LMO2-associated clonal T cell proliferation in two patients after gene therapy for SCID-X1. Science 302, 415-419.

Haggie, P.M., Stanton, B.A., \& Verkman, A.S. (2002). Diffusional mobility of the cystic fibrosis transmembrane conductance regulator mutant, dF508-CFTR, in the endoplasmic reticulum measured by photobleaching of GFP-CFTR chimeras. J. Biol. Chem. 277, 16419-16425.

Harvey, B.G., Leopold, P.L., Hackett, N.R., Grasso, T.M., Williams, P.M., Tucker, A.L., Kaner, R.J., Ferris, B., Gonda, I., Sweeney, T.D., Ramalingam, R., Kovesdi, I., Shak, S., \& Crystal, R.G. (1999). Airway epithelual CFTR mRNA expression in cystic fibrosis patients after repetitive administration of a recombinant adenovirus. J. Clin. Invest. 104, 1245-1255. 
Henning, P., Magnusson, M.K., Gunneriusson, E., Hong, S.S., Boulanger, P., Nygren, P. A., \& Lindholm, L. (2002). Genetic modification of Ad5 tropism by a novel class of ligands based on a three-helix bundle scaffold derived from staphylococcal protein A. Hum. Gene Ther. 13, 1427-1439.

Hida, K., Lai, S. K., Suk, J.S., Won, S.Y., Boyle, M.P., \& Hanes, J. (2011). Common gene therapy viral vectors do not efficiently penetrate sputum from cystic fibrosis patients. PLoS One 6(5), e19919.

Hong, S.S., Magnusson, M.K., Henning, P., Lindholm, L., \& Boulanger, P. (2003). Adenovirus (Ad) stripping: a novel method to generate liganded Ad vectors with new cell target specificity. Mol. Ther. 7, 692-699.

Inouye, S. \& Tsuji, F.I. (1994). Aequorea green fluorescent protein. Expression of the gene and fluorescence characteristics of the recombinant protein. FEBS Lett. 341, 277280.

Ito, S., Gotoh, E., Ozawa, S., \& Yanagi, K. (2002). Epstein-Barr virus nuclear antigen-1 is highly colocalized with interphase chromatin and its newly replicated regions in particular. J. Gen. Virol. 83, 2377-2383.

Kammouni, W., Moreau, B., Becq, F., Saleh, A., Pavirani, A., Figarella, C., \& Merten, M.D. (1999). A cystic fibrosis tracheal gland cell line, CF-KM4. Correction by adenovirusmediated CFTR gene transfer. Am. J. Respir. Cell Mol. Biol. 20, 684-691.

Kobinger, G.P., Schumer, G.P., Medina, M.F., Weiner, D.J. \& Wilson, J.M. (2003). Stable and efficient gene transfer in airway of non-human primates with HIV vector pseudotyped with deletion mutant of the Ebola envelope glycoproteins. Pediatr. Pulmonol. Suppl. 25, 256.

Kochanek, S., Clemens, P.R., Mitani, K., Chen, H.H., Chan, S., \& Caskey, C.T. (1996). A new adenoviral vector: replacement of all viral coding sequences with $28 \mathrm{~kb}$ of DNA independently expressing both full-length dystrophin and beta-galactosidase. Proc. Natl. Acad. Sci. USA 93, 5731-5736.

Kolb, M., Martin, G., Medina, M., Ask, K., \& Gauldie, J. (2006). Gene therapy for pulmonary diseases. Chest 130, 879-884.

Kremer, K.L., Dunning, K.R., Parsons, D.W., \& Anson, D.S. (2007). Gene delivery to airway epithelial cells in vivo: a direct comparison of apical and basolateral transduction strategies using pseudotyped lentivirus vectors. J. Gene Med. 9, 362-368.

Kreppel, F., \& Kochanek, S. (2004). Long-term transgene expression in proliferating cells mediated by episomally maintained high-capacity adenovirus vectors. J. Virol. 78, 9-22.

Kwilas, A.R., Yednak, M.A., Zhang, L., Liesman, R., Collins, P.L., Pickles, R.J. \& Peeples, M.E. (2010). Respiratory syncytial virus engineered to express the cystic fibrosis transmembrane conductance regulator corrects the bioelectric phenotype of human cystic fibrosis airway epithelium in vitro. J. Virol. 84, 7770-7781.

Lindahl, T., Adams, A., Bjursell, G., Bornkamm, G.W., Kasch-Dierich, C., \& Jehn, U. (1976). Covalently closed circular duplex DNA of Epstein-Barr virus in a human lymphoid cell line. J. Mol. Biol. 102, 511-530. 
Lippincott-Schwartz, J., \& Smith, C.L. (1997). Insights into secretory and endocytic membrane traffic using fluorescent protein chimeras. Curr. Opin. Neurobiol. 7, 631639.

Loffing-Cueni, D., Loffing, J., Shaw, C., Taplin, A.M., Govindan, M., Stanton, C.A., \& Stanton, B.A. (2001). Trafficking of GFP-tagged dF508-CFTR to the plasma membrane in a polarized epithelial cell line. Am. J. Physiol. Cell Physiol. 281, C1889C1897.

Lufino, M.M.P., Edser, P.A.H., \& Wade-Martins, R. (2009). Advances in high-capacity extrachromosomal vector technology: episomal maintenance, vector delivery and transgene expression. Mol. Ther. 16, 1525-1538.

Magnusson, M.K., Henning, P., Myhre, S., Wikman, M., Uil, T. G., Friedman, M., Andersson, K.M.E., Hong, S.S., Hoeben, R.C., Habib, N.A., Stahl, S., Boulanger, P., \& Lindholm, L. (2007). An Ad5 vector genetically re-targeted by an AffibodyTM molecule with specificity for tumor antigen HER2/neu. Cancer Gene Ther. 14, 468-479.

Magnusson, M.K., Hong, S.S., Boulanger, P., \& Lindholm, L. (2001). Genetic re-targeting of adenovirus: a novel strategy employing 'de-knobbing' of the fiber. J. Virol. 75, 72807289 .

McLachlan, G., Davidson, H., Holder, E., Davies, L.A., Pringle, I.A., Sumner-Jones, S.G., Baker, A., Tennant, P., Gordon, C., Vrettou, C., Blundell, R., Hyndman, L., Stevenson, B., Wilson, A., Doherty, A., Shaw, D.J., Coles, R.L., Painter, H., Cheng, S.H., Scheule, R.K., Davies, J.C., Innes, J.A., Hyde, S.C., Griesenbach, U., Alton, E.W., Boyd, A.C., Porteous, D.J., Gill, D.R., \& Collie, D.D. Pre-clinical evaluation of three non-viral gene transfer agents for cystic fibrosis after aerosol delivery to the ovine lung. (2011). Gene Ther. Epub ahead of print, doi:10.1038/gt.2011.55

Mei, W. H., Qian, G. X., Zhang, X. Q., Zhang, P., and Lu, J. (2006). Sustainied expression of Epstein-Barr virus episomal vector mediated factor VIII in vivo following muscle electroporation. Haemophilia 12, 271-279.

Merten, M.D., Kammouni, W., Renaud, W., Birg, F., Mattei, M.G., \& Figarella, C. (1996). A transformed human tracheal gland cell line, MM-39, that retains serous secretory functions. Am. J. Respir. Cell Mol. Biol. 15, 520-528.

Milanesi, G., Barbanti-Brodano, G., Negrini, M., Lee, D., Corallini, A., Caputo, A., Grossi, M.P., \& Ricciardi, R.P. (1984). BK virus-plasmid expression vector that persists episomally in human cells and shuttles into Escherichia coli. Mol. Cell Biol. 4, 15511560.

Milewski, M.I., Mickle, J.E., Forrest, J.K., Stafford, D.M., Moyer, B.D., Cheng, J., Guggino, W.B., Stanton, B.A., \& Cutting, G.R. (2001). A PDZ-binding motif is essential but not sufficient to localize the C terminus of CFTR to the apical membrane. J. Cell Sci. $114,719-726$.

Mitomo, K., Griesenbach, U., Inoue, M., Somerton, L., Meng, C., Akiba, E., Tabata, T., Ueda, Y., Frankel, G.M., Farley, R., Singh, C., Chan, M., Munkonge, F., Brum, A., Xenariou, S., Escudero-Garcia, S., Hasegawa, M., \& Alton, E.W. (2010). Toward 
gene therapy for cystic fibrosis using a lentivirus pseudotyped with Sendai virus envelopes. Mol. Ther., 18, 1173-1182.

Moss, R.B., Milla, C., Colomba, J., Accurso, F., Zeitlin, P.L., Clancy, J.P., Spencer, L.T., Pilewski, J., Waltz, D.A., Dorkin, H.L., Ferkol, T., Pian, M., Ramsey, B., Carter, B.J., Martin, D.B., \& Heald, A.E. (2007). Repeated aerosolized AAV-CFTR for treatment of cystic fibrosis: a randomised placebo-controlled phase 2B trial. Hum. Gene Ther. 18, 726-732.

Moyer, B.D., Loffing, J., Schwiebert, E.M., Loffing-Cueni, D., Halpin, P.A., Karlson, K.H., Ismailov, I.I., Guggino, W.B., Langford, G.M., \& Stanton, B.A. (1998). Membrane trafficking of the cystic fibrosis gene product, cystic fibrosis transmembrance conductance regulator, tagged with green fluorescent protein in Madin-Darby canine kidney cells. J. Biol. Chem. 273, 21759-21768.

Moyer, B.D., Loffing-Cueni, D., Loffing, J., Reynolds, D., \& Stanton, B.A. (1999). Butyrate increases apical membrane CFTR but reduces chloride secretion in MDCK cells. Am. J. Physiol. Renal Physiol. 277, F271-276.

O'Riordan, C.R., Lachapelle, A.L., Marshall, J., Higgins, E.A., \& Cheng, S.H. (2000). Characterization of the oligosaccharide conductance regulator. Glycobiology 10, 1225-1233.

Oceandy, D., McMorran, B., Schreiber, R., Wainwright, B.J., \& Kunzelmann, K. (2003). GFPtagged CFTR transgene is functional in the G551D cystic fibrosis mouse colon. J. Membrane Biol. 192, 159-167.

Otake, K., Ennist, D.L., Harrod, K., \& Trapnell, B.C. (1998). Nonspecific inflammation inhibits adenovirus-mediated pulmonary gene transfer and expression independent of specific acquired immune responses. Hum. Gene Ther. 9, 22072222.

Parks, R.J., Chen, L., Anton, M., Sankar, U., Rudnicki, M.A., \& Graham, F.L. (1996). A helper-dependent adenovirus vector system: removal of helper virus by Cremediated excision of the viral packaging signal. Proc. Natl. Acad. Sci. USA 93, 1356513570.

Perricone, M.A., Morris, J.E., Pavelka, K., Plog, M.S., O'Sullivan, B.P., Joseph, P.M., Dorkin, H., Lapey, A., Balfour, R., Meeker, D.P., Smith, A.E., Wadsworth, S.C., \& St George, J.A. (2001). Aerosol and lobar administration of a recombinant adenovirus to individuals with cystic fibrosis. ii. transfection efficiency in airway epithelium. Hum. Gene Ther. 12, 1383-1394.

Perricone, M.A., Rees, D.D., Sacks, C.R., Smith, K.A., Kaplan, J.M., \& St George, J.A. (2000). Inhibitory effect of cystic fibrosis sputum on adenovirus-mediated gene transfer in cultured epithelial cells. Hum. Gene Ther. 11, 1997-2008.

Piedra, P.A., Poveda, G.A., Ramsey, B., McCoy, K., \& Hiatt, P.W. (1998). Incidence and prevalence of neutralizing antibodies to the common adenoviruses in children with cystic fibrosis: implication for gene therapy with adenovirus vectors. Pediatrics 101, 1013-1019.

Pollard, H., Toumaniantz, G., Amos, J.L., Avet-Loiseau, H., Guihard, G., Behr, J.P. \& Escande, D. (2001). $\mathrm{Ca}^{2+}$-sensitive cytosolic nucleases prevent efficient delivery to the nucleus of injected plasmids. J. Gene Med. 3, 153-164. 
Prasher, D.C., Eckenrode, V.K., Ward, W.W., Prendergast, F.G. \& Cormier, M.J. (1992). Primary structure of the Aequorea victoria green-fluorescent protein. Gene 111, 229233.

Rawlins, D.R., Milman, G., Hayward, S.D., \& Hayward, G.S. (1985). Sequence-specific DNA binding of the Epstein-Barr virus nuclear antigen (EBNA-1) to clustered sites in the plasmid maintenance region. Cell 42, 859-868.

Rosenfeld, M.A., Yoshimura, K., Trapnell, B.C., Yoneyama, K., Rosenthal, E.R., Dalemans, W., Fukayama, M., Bargon, J., Stier, L.E., Stratford-Perricaudet, L., Perricaudet, M., Guggino, W.B., Pavirani, A., Lecocq, J.-P., \& Crystal, R.G. (1992). In vivo transfer of the human cystic fibrosis transmembrane conductance regulator gene to the airway epithelium. Cell 68, 143-155.

Scaria, A., St George, J.A., Jiang, C., Kaplan, J.M., Wadsworth, S.C., \& Gregory, R.J. (1998). Adenovirus-mediated persistent cystic fibrosis transmembrane conductance regulator expression in mouse airway epithelium. J. Virol. 72, 7302-7309.

Sheppard, D., \& Welsh, M.J. (1999). Structure and function of the CFTR chloride channel. Physiol. Rev. 79, S23-S45.

Shimomura, O., Johnson, F.H., \& Saiga, Y. (1962). Extraction, purification and properties of aequorin, a bioluminescent protein from the luminous hydromedusan, Aequorea. J. Cell Comp. Physiol. 59, 223-239.

Sinn, P.L., Williams, G., Vongpunsawad, S., Cattaneo, R., \& McCray Jr, P.B. (2002). Measles virus preferentially transduces the basolateral surface of well-differentiated human airway epithelia. J. Virol. 76, 2403-2409.

Sinn, P.L., Arias, A.C., Brogden, K.A. \& McCray, P.B. Jr (2008). Lentivirus vector can be readministered to nasal epithelia without blocking immune responses. J. Virol., 82, 10684-10692.

Sinn, P.L., Reshma, M.A., \& McCray Jr, P.B. (2011). Genetic therapies for cystic fibrosis lung disease. Human Mol. Genetics, 20, R79-R86.

Teramoto, S., Bartlett, J.S., McCarty, D., Xiao, X., Samulski, R.J., \& Boucher, R.C. (1998). Factors influencing adeno-associated virus-mediated gene transfer to human cystic fibrosis airway epithelial cells: comparison with adenovirus vectors. J. Virol. 72, 8904-8912.

Toh, M.L., Hong, S.S., van de Loo, F., Franqueville, L., Lindholm, L., van den Berg, W., Boulanger, P., \& Miossec, P. (2005). Enhancement of Ad-mediated gene delivery to rheumatoid arthritis synoviocytes and synovium by fiber modifications: role of RGD and non-RGD-binding integrins. J. Immunol. 175, 7687-7698.

Tsien, R.Y. (1998). The green fluorescent protein. Ann. Rev. Biochem. 67, 509-544.

Vais, H., Gao, G.P., Yang, M., Tran, P., Louboutin, J.P., Somanathan, S., Wilson, J.M., \& Reenstra, W.W. (2004). Novel adenoviral vectors coding for GFP-tagged wtCFTR and deltaCFTR: characterization of expression and electrophysiological properties in A549 cells. Pflugers Arch., 449, 278-287.

Vera, M., \& Fortes, P. (2004). Simian virus-40 as a gene therapy vector. DNA Cell Biol. 23, 271-282. 
Wagner, J.A., Messner, A.H., Moran, M.L., Daifuku, R., Kouyama, K., Desch, J.K., Manley, S., Norbash, A.M., Conrad, C.K., Friborg, S., Reynolds, T., Guggino, W.B., Moss, R.B., Carter, B.J., Wine, J.J., Flotte, T.R., \& Gardner, P. (1999). Safety and biological efficacy of an adeno-associated virus vector-cystic fibrosis transmembrane regulator (AAV-CFTR) in the cystic fibrosis maxillary sinus. Laryngoscope 109, 266274.

Wahlfors, J., Loimas, S., Pasanen, T., \& Hakkarainen, T. (2001). Green fluorescent protein (GFP) fusion constructs in gene therapy research. Histochem. Cell Biol. 115, 59-65.

Walters, R.W., Grunst, T., Bergelson, J.M., Finberg, W., Welsh, M.J., \& Zabner, J. (1999). Basolateral localization of fiber receptors limits adenovirus infection from the apical surface of airway epithelia. J. Biol. Chem. 274, 10219-10226.

Welsh, M.J., Zabner, J., Graham, S.M., Smith, A.E., Moscicki, R.A., \& Wadsworth, S.C. (1995). Adenovirus-mediated gene transfer for cystic fibrosis. Part A. Safety of dose and repeat administration in the nasal epithelium. Part B. Clinical efficacy in the maxillary sinus. Hum. Gene Ther. 6, 205-218.

Yates, J.L., Warren, N., \& Sugden, B. (1985). Stable replication of plasmids derived from Epstein-Barr virus in various mammalian cells. Nature 313, 812-815.

Yoo, H. S., Mazda, O., Lee, H. Y., Kim, J. C., Kwon, S. M., Lee, J. E., Kwon, I. C., Jeong, H., Jeong, Y. S., and Jeong, S. Y. (2006). In vivo gene therapy of type I diabetic mellitus using a cationic emulsion containing an Epstein-Barr virus-based plasmid vector. J. Control Release 112, 139-144.

Zabner, J., Couture, L.A., Gregory, R.J., Graham, S.M., Smith, A.E., \& Welsh, M.J. (1993). Adenovirus-mediated gene transfer transiently corrects the chloride transport defect in nasal epithelia of patients with cystic fibrosis. Cell 75, 207-216.

Zabner, J., Freimuth, P., Puga, A., Fabrega, A., \& Welsh, M.J. (1997). Lack of high affinity fiber receptor activity explains the resistance of ciliated airway epithelia to adenovirus infection. J. Clin. Invest. 100, 1144-1149.

Ziady, A.G., Kelley, T.J., Milliken, E., Ferkol, T., \& Davis, P.B. (2002). Functional evidence of CFTR gene transfer in nasal epithelium of cystic fibrosis mice in vivo following luminal application of DNA complexes targeted to the serpin-enzyme complex receptor. Mol. Ther. 5, 413-419.

Zhang, L., Peeples, M.E., Boucher, R.C., Collins, P.L., \& R. J. Pickles. (2002). Respiratory syncytial virus infection of human airway epithelial cells is polarized, specific to ciliated cells, and without obvious cytopathology. J. Virol. 76, 5654-5666.

Zhang, L., Bukreyev, A., Thompson, C.I., Watson, B., Peeples, M.E., Collins, P.L., \& Pickles, R.J. (2005). Infection of ciliated cells by human parainfluenza virus type 3 in an in vitro model of human airway epithelium. J. Virol. 79, 1113-1124.

Zhang, L., Button, B., Gabriel, S.E., Burkett, S., Yan, Y., Skiadopoulos, M.H., Dang, Y.L., Vogel, L.N., McKay, T., Mengos, A., Boucher, R.C., Collins, P.L., \& Pickles, R.J. (2009). CFTR delivery to $25 \%$ of surface epithelial cells restores normal rates of mucus transport to human cystic fibrosis airway epithelium. PLoS Biol. 7, e1000155. 
Zhang, L., Limberis, M.P., Thompson, C., Antunes, M.B., Luongo, C., Wilson J.M., Collins, P.L. \& Pickles, R.J. (2010). $\alpha$-fetoprotein gene delivery to the nasal epithelium of nonhuman primates by human parainfluenza viral vectors. Hum. Gene Ther. 21, 1657-1664. 


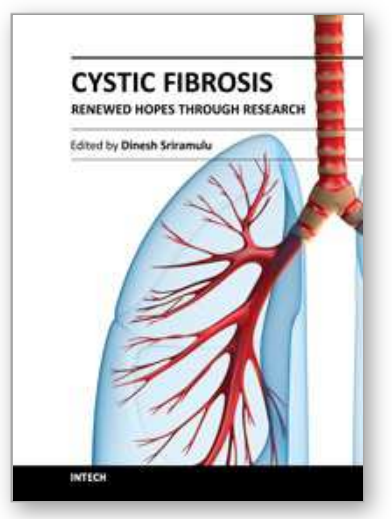

\author{
Cystic Fibrosis - Renewed Hopes Through Research \\ Edited by Dr. Dinesh Sriramulu
}

ISBN 978-953-51-0287-8

Hard cover, 550 pages

Publisher InTech

Published online 28, March, 2012

Published in print edition March, 2012

Living healthy is all one wants, but the genetics behind creation of every human is different. As a curse or human agony, some are born with congenital defects in their menu of the genome. Just one has to live with that! The complexity of cystic fibrosis condition, which is rather a slow-killer, affects various organ systems of the human body complicating further with secondary infections. That's what makes the disease so puzzling for which scientists around the world are trying to understand better and to find a cure. Though they narrowed down to a single target gene, the tentacles of the disease reach many unknown corners of the human body. Decades of scientific research in the field of chronic illnesses like this one surely increased the level of life expectancy. This book is the compilation of interesting chapters contributed by eminent interdisciplinary scientists around the world trying to make the life of cystic fibrosis patients better.

\title{
How to reference
}

In order to correctly reference this scholarly work, feel free to copy and paste the following:

Gaëlle Gonzalez, Pierre Boulanger and Saw-See Hong (2012). CFTR Gene Transfer and Tracking the CFTR Protein in the Airway Epithelium, Cystic Fibrosis - Renewed Hopes Through Research, Dr. Dinesh Sriramulu (Ed.), ISBN: 978-953-51-0287-8, InTech, Available from: http://www.intechopen.com/books/cystic-fibrosisrenewed-hopes-through-research/cftr-gene-transfer-and-tracking-the-cftr-protein-in-the-airway-epithelium

\section{INTECH}

open science | open minds

\author{
InTech Europe \\ University Campus STeP Ri \\ Slavka Krautzeka 83/A \\ 51000 Rijeka, Croatia \\ Phone: +385 (51) 770447 \\ Fax: +385 (51) 686166 \\ www.intechopen.com
}

\author{
InTech China \\ Unit 405, Office Block, Hotel Equatorial Shanghai \\ No.65, Yan An Road (West), Shanghai, 200040, China \\ 中国上海市延安西路65号上海国际贵都大饭店办公楼 405 单元 \\ Phone: +86-21-62489820 \\ Fax: +86-21-62489821
}


(C) 2012 The Author(s). Licensee IntechOpen. This is an open access article distributed under the terms of the Creative Commons Attribution 3.0 License, which permits unrestricted use, distribution, and reproduction in any medium, provided the original work is properly cited. 